e-ISSN: 2721-3013, p-ISSN: 2721-3005

DOI: https://doi.org/10.38035/jafm.v1i3

Received: 10 May 2020, Revised: 19 June 2020, Publish: 20 July 2020 https://creativecommons.org/licenses/by/4.0/

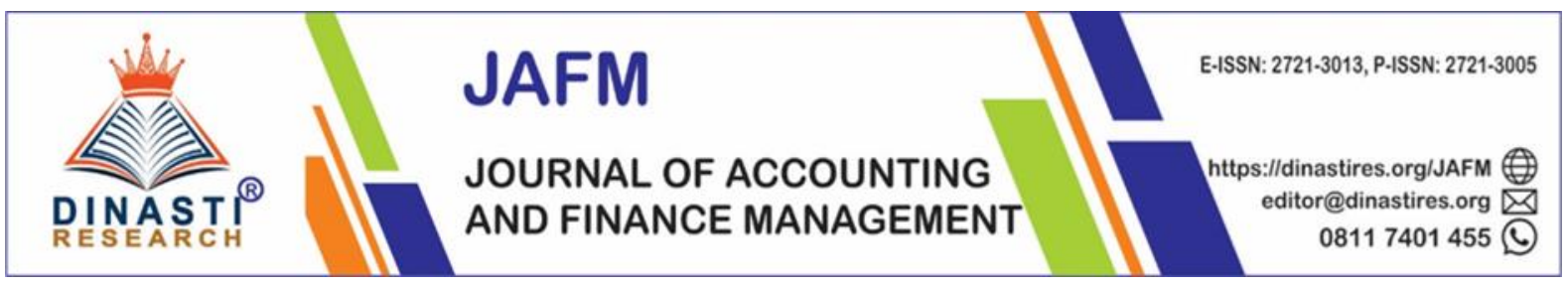

\title{
The Role of Corporate Governance in Constraining Earning Management
}

\author{
Dwi Jaya Kirana $^{1^{*}}$, Ekawati Jati Wibawaningsih ${ }^{2}$, Aniek Wijayanti ${ }^{3}$ \\ 1),2),3)Universitas Pembangunan Nasional Veteran Jakarta, Indonesia, email: \\ dwijayakirana@upnvj.ac.id \\ *Corresponding author : Dwi Jaya Kirana ${ }^{1}$
}

\begin{abstract}
This study examines whether corporate governance measured by audit quality, ownership structure, and board of commissioners quality has an effective role in constraining earnings management in Indonesia. The sample of this research is 163 companies in nonfinancial sectors listed on the Indonesia Stock Exchange in the period 2014-2018. Regression analysis is used to test the research hypothesis. Discretional accruals were used to measure earning management. The results show that the audit firm's reputation as a proxy of audit quality has a negative significant influence (at the 5\% level) on earning management practices. Contrary to the hypothesis, we found that the size of the board of commissioners has a positive significant influence (at the 5\% level) on earnings management. These findings provide practical advice for the government and shareholders in providing effective corporate governance mechanisms in constraining earnings management.
\end{abstract}

Keywords: Earning Management, Ownership Structure, Board of Directors Quality, Audit Quality, Corporate Governance

\section{INTRODUCTION}

The researchers began to research earnings management since Jensen and Meckling (1976) introduced the concept of agency theory. Schipper (1989) defining earnings management as an opportunistic behavior of managers which is done by manipulating the numbers in the financial statements with specific goals and objectives such as the desire to create stable financial performance reports.

Healy and Wahlen (1999) explain that earnings management occurs when managers change financial statements to mislead shareholders or to influence the outcome of contracts that depend on accounting numbers. The previous study noted the negative consequences of earnings management behavior, i.e the decrease in the level of trust between shareholders and the managers. Dechow et al., (1996) revealed that companies with practice earnings management experienced a decline of their share price up to 9 percent in the two years after the announcement of an investigation by the Securities and Exchange Commission (SEC). 
Earnings management research in various countries seeks to reveal what factors influence managers' incentives to engage in opportunistic behavior. Gonzales and Meca (2013) examined the phenomenon of earnings management in Latin America. They use corporate governance variables and find that internal ownership, ownership concentration, the board size, and board activity are factors that can prevent earnings management. Yang et al., (2012) discuss corporate governance related to earnings management practices in China. It was found that corporate governance variables such as the size of the supervisory board, the frequency of the supervisory board, insider ownership, the size of the board of directors, and the independence of the board of directors were proven to significantly improve earnings management in China. Conversely, the presence of an audit committee and audit reputation can significantly be a barrier.

Usually, the motive of earnings management is done by the company to increase the performance or value of the company. And Corporate Governance plays an important role in the company's performance and value (Kirana, 2019). So corporate governance can play a role to avoid earning management. Alves (2012) examined the effect of corporate governance variables consisting of managerial ownership, ownership concentration, and institutional ownership on earnings management in Portugal. His findings show that managerial ownership and ownership concentration provide effective monitoring for earnings management practices, which means that these two variables can inhibit earnings management in Portugal. Memis and Cetenak (2012) conducted a comparative study of 1507 companies in 8 countries that investigated the relationship between audit quality and earnings management. The results show that audit quality can hamper earnings management in Brazil and Mexico, but this does not apply to the other 6 countries.

This research tries to investigate the role of corporate governance in constraining earnings management practices in Indonesia. The results of this study are expected to provide empirical evidence to answer the question of how effective is the role of corporate governance variable consist of audit quality, ownership structure, and the quality of the board of commissioners in inhibiting earnings management in Indonesia.

\section{LITERATURE REVIEW}

\section{Audit Quality and Earning Management}

Previous literature proves that higher audit quality will hinder earnings management. Audit quality is a function of auditor ability that can be explained through two dimensions (De Angelo, 1981). First is the dimension of technical ability which refers to the ability of auditors to detect material misstatements and errors in financial statements. The second is auditor independence which refers to the auditor's commitment to reporting misstatements and errors that he finds in the financial statements. The measurement of audit quality most often used in various previous studies is the reputation of KAP and auditor rotation (Lin and Hwang, 2010; Chadegani, 2011; Yang, Tan, and Ding, 2012; Memis and Cetenak, 2012; Chi, et al., 2011).

\section{Audit Firm's Reputation}

The auditor's reputation can be measured by identifying whether an audit firm is classified as Big 4 or not. Audit firms that are classified as Big 4 can be assumed as a large audit firm. According to De Angelo (1981), the larger audit firm size indicates better audit quality because a large audit firm has better capabilities in carrying out audits. Big 4 audit firm is believed to provide or maintain a higher level of audit quality (De Angelo, 1981; Watts and Zimmerman, 1986) since they have a greater number of clients, the ability to provide higher quality resources ( Krishnan, 2003), and have a higher risk of losing 
reputation if they do not reveal the mistakes they find in the financial statements that they examine (Chung et al., 2005).

Evidence from previous research reveals that an audit firm's reputation can be a barrier to earnings management practices. The number of Big 4 client companies that reported carrying out earnings management practices proved to be lower than the number of Non-Big 4 client companies (Becker et al., 1998). Other research conducted by Kanagaretnam et al. (2010) in the banking industry also found that the type of auditor (Big 5 or Non-Big 5) can inhibit earnings management, as well as the findings of research conducted by Memis and Cetenak (2012) in Brazil and Mexico. Based on the analysis of the literature, the first hypothesis proposed in this study is as follows:

H1: Audit firm's reputation has a negative influence on earnings management.

\section{Auditor Rotation}

In Indonesia, based on the Government Regulation of the Republic of Indonesia Number 20 the Year 2015 about Public Accountant Practices, Article 11 regulates that the provision of audit services on historical financial information provided by a Public Accountant to an entity is limited to a maximum of 5 (five) years. The length of the engagement period between the auditor and the client is claimed to increase the auditor's insight about the client's operations and business and control over his financial statements (Arens et al., 2012) so that the auditor will be better in assessing the risk of material misstatement. However, findings from previous studies reveal that the period of engagement between the auditor and the client can affect auditor independence. The longer the engagement period will reduce auditor independence (Lys and Watts, 1994). Disruption of auditor independence will reduce audit quality and increase the likelihood of earnings management (Yang and Krishnan, 2005). Based on the analysis of the literature, the second hypothesis proposed in this study is as follows:

H2: Auditor rotation has a negative influence on earnings management.

\section{Ownership Structure and Earning Management}

Agency theory explains that the separation between the ownership function and the manager function creates a conflict of interest between managers and shareholders (Jensen and Meckling, 1976). Therefore, monitoring managerial decisions is important to ensure the interests of shareholders are protected, also ensuring the reliability of the information presented in the financial statements. Previous researchers have argued that corporate governance mechanisms can restrict managerial opportunism (Fama, 1980; Fama and Jensen, 1983; and Williamson, 1988). The ownership structure of a company is believed to be one of the effective corporate governance mechanisms for monitoring managers in making decisions, minimizing the possibility of earnings management practices, and improving the quality of earnings that presented in the financial statement (Donnelly and Lynch, 2002; Fan and Wong, 2002; Alves, 2012; Gonzales and Meca, 2013).

\section{Ownership Concentration}

Several studies have found that ownership concentration will reduce earnings management practices (Iturriaga and Hoffmann, 2005; Alves, 2012; Gonzales and Meca, 2013). Based on the efficient monitoring hypothesis, the greater the concentration of ownership, the more effective it is in reducing the opportunistic behavior of managers and encouraging managers' tendencies to maximize firm value (Fama, 1980; Fama and Jensen, 1983). The finding of research conducted by Bos and Donker (2004) is in line with the efficient monitoring hypothesis. It shows that increasing ownership concentration can be an effective governance mechanism for monitoring management decisions, such as changes in 
the use of accounting methods. Based on the analysis of the literature, the third hypothesis proposed in this study is as follows:

H3: The concentration of ownership has a negative influence on earnings management.

\section{Institutional Ownership}

The existence of institutional investors provides an external monitoring mechanism that can limit the opportunistic behavior of managers in manipulating profits. Monks and Minow (1995) state that institutional investors have the opportunity, resources, and ability to monitor, discipline, and influence company managers, which is difficult for smaller and more passive investors to do (Almazan et al., 2005). Several studies have found that institutional ownership can prevent managers from carrying out earnings management (Bange and De Bondt, 1998; Chung et al., 2002; Cornett et al., 2009). Based on the analysis of the literature, the fourth hypothesis proposed in this study is as follows:

H4: Institutional ownership has a negative influence on earnings management.

\section{Quality of The Board of Commissioners and Earning Management}

According to the regulation of the Financial Services Authority (OJK) No. 57 / POJK.04 / 2017, the task of the board of commissioners is to supervise and provide advice to directors. The board of commissioners is an important element of corporate governance that provides an internal control mechanism in reducing agency conflicts that occur between managers and shareholders, as well as between majority shareholders and minority shareholders (Lafond and Roychowdhury, 2006). Previous studies discuss several governance variables that affect the quality of the board of directors in monitoring managers. These variables include the size, independence, and activities of the board of directors (Gonzales and Meca, 2013).

\section{Size of The Board of Commissioners}

Income manipulation practices are said to be related to weak oversight of management (Dechow, et al., 1996). If the board size is very small, then the level of monitoring of management also becomes lower, so managers tend to do earnings management to get higher remuneration (Brick et al., 2006). Soliman and Ragab (2013) study in Egypt found the same results with previous studies, where the size of the board of commissioners had a negative effect on earnings management. Research by Gonzales and Meca (2013) and Lin and Hwang (2011) also found similar findings. Based on the analysis of the literature, the fifth hypothesis proposed in this study is as follows:

H5: The size of the board of commissioners has a negative influence on earnings management.

\section{Independence of the Board of Commissioners}

The regulation of the Financial Services Authority (OJK) No. 57 / POJK.04 / 2017 states that independent commissioners are members of the board of commissioners who come from outside the company. Companies that are listed in Indonesia Stock Exchange must have independent commissioners with a minimum percentage of $30 \%$ of the total members of the board of commissioners. Previous research found an indication that systematic income manipulation was related to weak oversight of management, it was stated that companies with greater levels of income manipulation were very likely to have a board of directors dominated by an insider (Xie et al., 2003; Jaggi, et al., 2009). Empirical evidence from several studies shows that the existence of an external commissioner can constrain earnings management. The greater the percentage of external commissioners is proven to be able to improve the quality of financial statements and information disclosed by the company, thus meaning that earnings management practices can be minimized (Xie et al., 2003; Davidson et al., 2005; 
Jaggi, et al., 2009, Lin and Hwang, 2011). Based on the analysis of the literature, the sixth hypothesis put forward in this study is as follows:

H6: The independence of the board of directors has a negative influence on earnings management.

\section{Board of Commissioners' Activities}

Measuring the quality of the board of commissioners only by their size and independence is considered inadequate (Gonzales and Meca, 2013). Another proxy that can be used to complete the quality measurement of the board of commissioners is their activities, which is measured based on the number of meetings held by the board of commissioners (Yang, et al., 2012; Gonzales and Meca, 2013). The higher the frequency of meetings held, the board of commissioners of a company is considered to be more active and able to hinder earnings management (Gulzar, 2011). This is in line with the findings of Firth et al., (2007) which revealed that large companies with active supervisory boards were able to improve the quality of financial statements. Based on the analysis of the literature, the seventh hypothesis in this study is as follows:

H7: The activities of the board of commissioners have a negative influence on earnings management.

\section{Control Variable}

Company size is used as a control variable in this study with the consideration that this variable influences earnings management. Company size is calculated using the natural logarithm of total assets. It is expected that the greater of the size of a company will reduce earnings management related to the company's efforts to maintain its reputation and the existence of tighter supervision from the government to large companies (Dechow and Dichev, 2002).

\section{RESEARCH METHODS}

The population of this study was 673 companies listed on the Indonesia Stock Exchange (IDX) during the 2014-2018 period. This study only made observations on companies in the non-financial sector. After deducting companies in the financial and investment sectors, as well as companies with incomplete data, a final sample of this study was obtained by 165 companies. Data is collected from financial reports available on the IDX website (idx.co.id).

\section{Measurement of Earning Management}

Earnings management is measured using discretionary accruals (DA). The Jones Modification Model focuses on Total Accrual (TA) which is considered to be able to detect greater management manipulation. Dechow et al (1995) state that Jones's model implicitly assumes that changes in credit sales are events of earnings management. This is based on the fact that it is easier to manage income from a recognition of income from sales of credit than to recognition of income from cash sales.

1. Calculate the total accruals using the Jones Model (Dechow, 1995) of the company measured by the formula below:

$$
\mathrm{TA}_{\mathrm{t}}=N I_{i t}-O C F_{i 1}
$$

Where, $\mathrm{TA}_{\mathrm{i}, \mathrm{t}}$ is total Accrual in year $t$; $\mathrm{NI}_{\mathrm{i}, \mathrm{t}}$ is net income to a company $i$ at year $t$; $\mathrm{OCF}_{\mathrm{i}, \mathrm{t}}$ is Operating Cash Flow to a company $i$ in year $\mathrm{t}$

2. Calculating the Total Accruals estimated with the OLS regression equation to determine the values of $\alpha 1, \alpha 2$, and $\alpha 3$. 


$$
\mathbf{T A}_{\mathrm{i}, \mathrm{t}}=\boldsymbol{\alpha}_{1}\left(1 / \mathbf{A}_{\mathrm{i}, \mathrm{t}}\right)+\boldsymbol{\alpha}_{2}\left(\Delta \operatorname{Rev}_{i, t} /_{\mathbf{A}_{\mathrm{i}, \mathrm{t}}}\right)+\boldsymbol{\alpha}_{3}\left(\mathrm{PPE}_{\mathrm{t} / \mathbf{A}_{\mathrm{i}, \mathrm{t}}}\right)+\mathbf{e}
$$

Where, $\mathrm{TA}_{\mathrm{i}, \mathrm{t}}$ is the total accruals to company $i$ at year $t ; \Delta \mathrm{ReV}_{\mathrm{i}, \mathrm{t}}$ is the change in the operating revenue to a company $i$ between year $t-1$ and $t, \Delta P P E_{i, t}$ is the gross property, plant, and equipment for a company $i$ at year $t$; Ai,t is the total assets to a company $i$ at the end of the prior year; and DRECijt is the change in receivables to a company $i$ between year $\mathrm{t}-1$ and $\mathrm{t} ; e$ is residuals, which indicate the company's specific discretionary share of total assets

3. Calculate the value of nondiscretionary accruals with the following formula

$$
\operatorname{NDA}_{i, t}=\alpha_{1}\left(1 / A_{i, t}\right)+\alpha_{2}\left(\left(\Delta \operatorname{Rev}_{i, t}-\Delta \operatorname{Rec}_{i, t}\right)_{A_{i, t}}\right)+\alpha_{3}\left(\operatorname{PPE}_{t} / A_{i, t}\right)
$$

Where, $\mathrm{NDA}_{\mathrm{i}, \mathrm{t}}$ is Nondiscretionary Accruals to a company $i$ at year $t ; \alpha_{1}, \alpha_{2}, \alpha_{3}$ is coefficients assessed

4. Calculating discretionary accruals with the modified Jones Model based on Dechow et al. (1995):

$$
D A_{i, t}=\left(T A_{i, t}\right)-N D A_{i, t}
$$

The $\mathrm{DA}_{\mathrm{i}, \mathrm{t}}$ is discretionary accrual (abnormal accrual rate) of a company $i$ in year $t$

\section{Research Model}

Multiple Linear Regression Analysis is used based on the reason of because it can explain the dependence of a dependent variable with one or more independent variables. The research models in this study are :

\begin{tabular}{|c|c|c|}
\hline Variable & Acronym & Measurement \\
\hline \multicolumn{3}{|l|}{ Dependent Variable } \\
\hline Earning Management & DA & Discretionary accruals \\
\hline \multicolumn{3}{|l|}{ Independent Variable } \\
\hline $\begin{array}{l}\text { Audit Firm Reputation (Big } 4 \\
\text { or Non-Big 4) }\end{array}$ & AUDREP & $\begin{array}{l}\text { A Dummy variable is used: given } 1 \text { if the audit firm } \\
\text { classified on big } 4,0 \text { if not }\end{array}$ \\
\hline Auditor Rotation & AUDROT & $\begin{array}{l}\text { A Dummy variable is used: given } 1 \text { if a company changes } \\
\text { its auditor after } 5 \text { years, } 0 \text { if it does not change the auditor } \\
\text { after } 5 \text { years. }\end{array}$ \\
\hline Ownership Concentration & OWNCON & Percentage of shares owned by majority shareholders \\
\hline Institutional Ownership & INSTOWN & Percentage of shares owned by the institution \\
\hline $\begin{array}{l}\text { Size of the Board of } \\
\text { Commissioners }\end{array}$ & COMSIZE & Number of Commissioners \\
\hline Independence Commissioners & INDCOM & $\begin{array}{l}\text { A dummy variable is used, given } 1 \text { if the number of } \\
\text { independent/external commissioners is more than the } \\
\text { internal commissioners, } 0 \text { if vice versa. }\end{array}$ \\
\hline $\begin{array}{l}\text { Board of Commissioners' } \\
\text { Activities }\end{array}$ & BOACT & the number of meetings held by the board of commissioners \\
\hline \multicolumn{3}{|l|}{ Control Variable } \\
\hline Company Size & SIZE & Logarithms of Total Assets \\
\hline
\end{tabular}

$$
\begin{gathered}
D A_{i, t}=\beta_{0}+\beta_{1} A U D R E P+\beta_{2} A U D R O T+\beta_{3} O W N C O N S+\beta_{4} I N S T O W N+\beta_{5} C O M S I Z E+\beta_{6} I N D C O M \\
+\beta_{7} B O A C T++\beta_{8} S I Z E+\varepsilon
\end{gathered}
$$

Table 1. Variable Measurement 


\section{FINDINGS AND DISCUSSION Findings}

Based on Table 2, of the 777 companies that used the big four KAP services, it was $53.2 \%$, compared to the non-big four KAP which was only $46.8 \%$. The results of frequency statistic for AUDROT have a frequency of $65 \%$ for companies that do auditors and $35 \%$ of 777 companies do not change auditors within 5 years, which indicates that as many as $65 \%$ of the sample companies in this study rotate. auditors once every five years. It means that $65 \%$ of the companies have followed the government of the Government Regulation of the Republic of Indonesia Number 20 the Year 2015 which regulates that the auditor is allowed to audit for 5 years in a row.

Table 2. Frequency Statistics

\begin{tabular}{|c|c|c|c|c|c|}
\hline \multicolumn{6}{|c|}{ AUDREP } \\
\hline & & Frequency & Percent & Valid Percent & Cumulative Percent \\
\hline \multirow[t]{3}{*}{ Valid } & 0 & 364 & 46,8 & 46,8 & 46,8 \\
\hline & 1 & 413 & 53,2 & 53,2 & 100 \\
\hline & Total & 777 & 100 & 100 & \\
\hline \multicolumn{6}{|c|}{ AUDROT } \\
\hline & & Frequency & Percent & Valid Percent & Cumulative Percent \\
\hline \multirow[t]{3}{*}{ Valid } & 0 & 272 & 35,0 & 35,0 & 35,0 \\
\hline & 1 & 505 & 65,0 & 65,0 & 100 \\
\hline & Total & 777 & 100 & 100 & \\
\hline
\end{tabular}

Source : Secondary data processed

Table 3. Descriptive Statistics

\begin{tabular}{llllll}
\hline Variabel & Obs & Mean & Std. Dev. & Min. & Max. \\
\hline DA & 777 & 0.088 & 0.076 & -0.174 & 0.333 \\
\hline OWNCONS & 777 & 0.431 & 0.307 & 0.00 & 0.982 \\
\hline INSTOWN & 777 & 0.613 & 0.274 & 0.00 & 0.998 \\
\hline COMSIZE & 777 & 4.084 & 1.800 & 0.00 & 10.000 \\
\hline INDCOM & 777 & 0.348 & 0.169 & 0.00 & 1.000 \\
\hline BOACT & 777 & 13.927 & 14.688 & 0.00 & 120.000 \\
\hline SIZE & 777 & 14.985 & 1.699 & 11.227 & 19.658 \\
\hline
\end{tabular}

Table 3 show descriptive statistics from this research data. Earnings management measured by Discretionary Accruals (DA) has the minimum value of $-0,174$ and a maximum value of 0,333 , and an average value of 0,088 . Test results on OWNCONS, showed that the average concentration of share ownership was $43,1 \%$, with the largest value of ownership being $98,2 \%$. COMSIZE test results showed that the number of boards in a company has an average of 4 people. INSTOWN test results showed an average of 0,613 , which showed that the company's shares in this study were owned by institutions by $61,3 \%$. The descriptive statistical test also shows that there are companies with $99,8 \%$ of the shares owned by institutions. INDCOM statistical test showed that the average company has some independent directors is greater than the number of an internal commissioner in this study was $33,8 \%$. BOACT statistical test shows that the average activity of the board of commissioners is 14 activities each year. SIZE as a control variable measured by the natural logarithm of the total assets of the company, the average size of the sample company is 14,99 , a minimum value of 11,23 , and a maximum value of 19,66 . 


\section{Discussion}

Table 3 shows the results of the regression test between the dependent variable and the independent variable. The test results show that the relationship between earnings management and AUDREP is significant and negative. These results indicate that the reputation of the Big four can be used as a guarantee for the quality of audit results. Big four as an independent party that can minimize earnings management which distorts the reliability of financial statement information. This study has the same results as the study conducted by De Angelo (1981), Watts and Zimmerman (1986), Caneghem (2004), dan Krishnan (2003), who stated that Big four had better knowledge and experience so that their audit quality can be trusted. Also, Big four has a reputation risk if something goes wrong in the audit process (Chung, et al., 2005).

The test results showed AUDROT does not affect earnings management. Based on the results of descriptive statistics show that $65 \%$ of sample companies rotate auditors every 5 years, this shows that the mechanism is not effective in constraining earnings management. This study does not support the opinion of the engagement period between the auditor and the client that will increase the auditor's insight about operations and business (Arens et al., 2012) so that the auditor will be better at raising the risk of material misstatement. This finding can be a consideration for regulators to review the permissible engagement period to maintain auditor independence.

Table 4. Regression Analysis

\begin{tabular}{lccc}
\hline \multicolumn{1}{c}{ Variable } & Predict & \multicolumn{2}{c}{ DA } \\
\cline { 3 - 4 } & & Unstand. Coef. & T \\
\hline Const & & 0.008 & 0.31 \\
\hline AUDREP & - & -0.013 & $-2.252^{* *}$ \\
\hline AUDROT & - & -0.003 & -0.549 \\
\hline OWNCONS & - & -0.016 & $-1.612^{*}$ \\
\hline INSTOWN & - & -0.006 & -0.498 \\
\hline COMSIZE & - & 0.004 & $2.171^{* *}$ \\
\hline INDCOM & - & 0.016 & 0.957 \\
\hline BOACT & - & $-3.13 E-05$ & -0.162 \\
\hline SIZE & - & 0.005 & $2.930^{* *}$ \\
\hline F-Value & & 3.571 & \\
\hline Sig & & .000 & \\
\hline R Square & & .036 & \\
\hline N & & 777 & \\
\hline
\end{tabular}

OWNCONS test results on earnings management showed a weak relationship, but there is a direction of a negative relationship between the two. Thus, the results of this study support the opinion that the greater concentration of ownership will reduce the manager's opportunistic behavior and encourage managers' tendency to maximize the value of the company (Fama, 1980; Fama and Jensen, 1983). However, this research cannot support that increasing the concentration of ownership will be an effective governance mechanism for monitoring management decisions.

The test results show there is no INSTOWN effect on earnings management. Research conducted by Yang et al (2009) shows the same results as this study. Based on this research, it was found that most of the institutional shareholders were temporary shareholders who focused on short-term earnings approval, so they preferred financial statements that produced 
a good profit rate. This encourages company management to conduct earnings management to report earnings as desired by short-term investors.

The test results show a positive and significant effect between COMSIZE and earnings management, which means that the greater number of boards of commissioners can increase earnings management practices. The results of this study do not support the hypotheses that were built, but these results are in line with the results of research conducted by Santiago and Brown (2009). According to Yermack (1996) and Jensen (1993), the higher number of commissioners causes ineffective communication and coordination of the work of each member of the board of commissioners. This makes it difficult for the board of commissioners to supervise and control the actions of management, and constrained in making decisions for the company.

The test results show INDCOM no effect on earnings management. This result is in line with Yu (2006). Descriptive statistics results show that the average company that has some independent commissioners is greater than the number of internal commissioners in a sample company is $33,8 \%$. This may explain the possibility that the low level of independent percentage of commissioners causes the supervision of the board of commissioners on management to be weak. Thus, these findings provide recommendations to regulators to review the minimum percentage of independent commissioners' provisions on the total number of boards, so that supervision becomes more effective.

The results showed no influence between BOACT on earnings management. This finding is in line with research conducted by Lorca et al (2011), which found that the number of meetings held by the board of commissioners was not a significant activity to control management. This is because the implementation of the board of commissioners' meeting spends a short time discussing company policies in practice.

The control variable used by SIZE has significant and positive results, where the larger the size of the company, the higher the earnings management that occurs. This result is in line with the research of Dechow and Dichev (2002).

\section{CONCLUSION}

This study aims to examine the role of corporate governance measured by audit quality, ownership structure, and board of commissioner's quality in constraining earnings management in Indonesia. Regression analysis is used to test the research hypothesis. The results show that the audit firm's reputation as a proxy of audit quality and ownership concentration as a proxy of ownership structure, have a negative significant influence (at the $5 \%$ level) on earning management practices. It means that the two variables can be an effective mechanism in inhibiting earnings management. Shareholders may use audit services from big 4 audit firms as a way to supervise management. Besides, this study proves that the higher the concentration of ownership the lower the earnings management, meaning that the majority of shareholders can control management behavior and decisions. These findings supported a previous study conducted by De Angelo (1981), Watts and Zimmerman (1986), Becker et al (1998), Fama (1980), Fama and Jensen (1983).

Contrary to the hypothesis, we found that the size of the board of commissioners has a positive influence (at the $10 \%$ level) on earnings management, but the relationship between those variables is weak. It may explain that the larger number of boards will be rising a problem in coordination, this condition may lead to effective monitoring and control in management. This result is similar to a previous study conducted by Santiago and Brown (2009). While other variables, consisting of auditor rotation, institutional ownership, independence commissioners, and the activities of the board of commissioners were found to have no significant influence on earnings management. These findings provide practical 
advice for the government and shareholders in providing effective corporate governance mechanisms to constrain earnings management.

\section{REFERENCES}

Almazan, A., Hartzell, J. C., \& Starks, L. T. (2005). Active institutional shareholders and costs of monitoring: Evidence from executive compensation. Financial management, 34(4), 5-34.

Alves, S. (2012). Ownership structure and earnings management: Evidence from Portugal. Australasian Accounting, Business and Finance Journal, 6(1), 57-74.

Arens, A. A., Elder, R. J., \& Mark, B. (2012). Auditing and assurance services: an integrated approach. Boston: Prentice-Hall.

Bange, M. M., \& De Bondt, W. F. (1998). R\&D budgets and corporate earnings targets. Journal of Corporate Finance, 4(2), 153-184.

Becker, C. L., DeFond, M. L., Jiambalvo, J., \& Subramanyam, K. R. (1998). The effect of audit quality on earnings management. Contemporary accounting research, 15(1), 1-24.

Bos, A. D., \& Donker, H. (2004). Monitoring accounting changes: empirical evidence from the Netherlands. Corporate Governance: An International Review, 12(1), 60-73.

Brick, I. E., Palmon, O., \& Wald, J. K. (2006). CEO compensation, director compensation, and firm performance: Evidence of cronyism?. Journal of Corporate Finance, 12(3), 403-423.

Caneghem, V.T. (2004). The impact of audit quality on earnings rounding-up behavior: some UK evidence. European Accounting Review, 13(4), 771-786.

Chadegani, A. (2011). Review of studies on audit quality. Available at SSRN 2227359.

Chi, W., Lisic, L. L., \& Pevzner, M. (2011). Is enhanced audit quality associated with greater real earnings management?. Accounting Horizons, 25(2), 315-335.

Chung, R., Firth, M., \& Kim, J. B. (2002). Institutional monitoring and opportunistic earnings management. Journal of corporate finance, 8(1), 29-48.

Cornett, M. M., McNutt, J. J., \& Tehranian, H. (2009). Corporate governance and earnings management at large US bank holding companies. Journal of Corporate finance, 15(4), 412-430.

Davidson, R., Goodwin-Stewart, J., \& Kent, P. (2005). Internal governance structures and earnings management. Accounting \& Finance, 45(2), 241-267.

DeAngelo, Linda Elizabeth. 1981. Auditor Size and Audit Quality. Journal of Accounting and Economics 3 183-199.

Dechow, P. M., Sloan, R. G., \& Sweeney, A. P. (1995). Detecting earnings management. Accounting review, 193-225.

Dechow, P., Sloan, R., Sweeney, A., 1996. Causes and consequences of earnings management: An analysis of firms subject to enforcement actions by the SEC. Contemporary Accounting Research 13 (2), 1-36.

Donnelly, R., \& Lynch, C. (2002). The ownership structure of UK firms and the informativeness of accounting earnings. Accounting and Business Research, 32(4), 245-257.

Fama, E. F. (1980). Agency problems and the theory of the firm. Journal of political economy, 88(2), 288-307.

Fan, J. P., \& Wong, T. J. (2002). Corporate ownership structure and the informativeness of accounting earnings in East Asia. Journal of accounting and economics, 33(3), 401-425.

Firth, M., Fung, P. M., \& Rui, O. M. (2007). How ownership and corporate governance influence chief executive pay in China's listed firms. Journal of Business Research, 60(7), 776-785. 
González, J. S., \& García-Meca, E. (2013). Does corporate governance influence earnings management in Latin American markets?. Journal of Business Ethics, 121(3), 419-440.

Gulzar, M. A. (2011). Corporate governance characteristics and earnings management: Empirical evidence from Chinese listed firms. International Journal of Accounting and Financial Reporting, 1(1), 133.

Healy, P. M., \& Wahlen, J. M. (1999). A review of the earnings management literature and its implications for standard setting. Accounting Horizons, 13(4), 365-383.

Iturriaga, F. J. L., \& Hoffmann, P. S. (2005). Earnings management and internal mechanisms of corporate governance: Empirical evidence from Chilean firms. Corporate Ownership \& Control, 3(1), 17-29.

Jaggi, B., Leung, S., \& Gul, F. (2009). Family control, board independence, and earnings management: Evidence-based on Hong Kong firms. Journal of Accounting and Public Policy, 28(4), 281-300.

Jensen, M. C., \& Meckling, W. H. (1976). Theory of the firm: Managerial behavior, agency costs, and ownership structure. Journal of Financial Economics, 3(4), 305-360.

Kanagaretnam, K., Lim, C. Y., \& Lobo, G. J. (2010). Auditor reputation and earnings management: International evidence from the banking industry. Journal of Banking \& Finance, 34(10), 2318-2327.

Kirana, D. J. (2019). Peranan Corporate Governance Dalam Meningkatkan Kinerja Perusahaan Family Ownership Di Indonesia. Management \& Accounting Expose, 1(2).

Krishnan, G. V. (2003). Does Big 6 auditor industry expertise constrain earnings management?. Accounting Horizons, 17, 1-16.

Lafond, R., \& Roychowdhury, S. (2008). Managerial ownership and accounting conservatism. Journal of accounting research, 46(1), 101-135.

Lin, J. W., \& Hwang, M. I. (2010). Audit quality, corporate governance, and earnings management: A meta-analysis. International Journal of Auditing, 14(1), 57-77.

Lorca, C., Sánchez-Ballesta, J. P., \& García-Meca, E. (2011). Board effectiveness and cost of debt. Journal of business ethics, 100(4), 613-631.

Lys, T., \& Watts, R. L. (1994). Lawsuits against auditors. Journal of accounting research, 32, 65-93.

Memis, M. U., \& Cetenak, E. H. (2012). Earnings management, audit quality, and legal environment: An international comparison. International Journal of Economics and Financial Issues, 2(4), 460-469.

Monks, R. A. G., \& Minow, N. (1995). Corporate governance on equity ownership and corporate value. Journal of Financial Economics, 20, 293-315.

Santiago, M., \& Brown, C. J. (2009). An empirical analysis of Latin American board of directors and minority shareholders' rights. In Forum Empresarial (Vol. 14, No. 2, pp. 1-18). Centro de Investigaciones Comerciales e Iniciativas Académicas.

Schipper, M. (1989). Beyond the boundaries: African literature and literary theory. Allison \& Busby

Soliman, M. M., \& Ragab, A. A. (2014). Audit committee effectiveness, audit quality, and earnings management: an empirical study of the listed companies in Egypt. Research Journal of Finance and Accounting, 5(2), 155-166.

Watts, R. L., \& Zimmerman, J. L. (1986). Positive accounting theory.

Williamson, O. E. (1988). Corporate finance and corporate governance. The journal of finance, 43(3), 567-591.

Xie, B., Davidson III, W. N., \& DaDalt, P. J. (2003). Earnings management and corporate governance: the role of the board and the audit committee. Journal of corporate finance, 9(3), 295-316 
Yang, C. Y., Tan, B. L., \& Ding, X. (2012). Corporate governance and income smoothing in China. Journal of Financial Reporting and Accounting.

Yermack, D. (1996). Higher market valuation of companies with a small board of directors. Journal of financial economics, 40(2), 185-211.

Yu, F. (2006). Corporate governance and earnings management. Carlson School of Management, University of Minnesota, Minneapolis. 